\title{
PEMBUATAN FILM WISATA SEBAGAI MEDIA PROMOSI PARIWISATA DI DESA RUMAH GALUH KABUPATEN LANGKAT
}

\author{
Samerdanta Sinulingga \\ D3 Perjalanan Wisata Universitas Sumatera Utara \\ Email: summerantha@yahoo.com \\ Jhonson Pardosi \\ D3 Perjalanan Wisata Universitas Sumatera Utara \\ Email: jhonsonpardosi@yahoo.com \\ Nur Cahaya Bangun \\ D3 Perjalanan Wisata Universitas Sumatera Utara \\ Email: noerbangun60@gmail.com \\ Hotlan Siahaan \\ D3 Perpustakaan Universitas Sumatera Utara \\ Email: hotlansiahaan2016@yahoo.com
}

\begin{abstract}
Film and tourism during the 4.0 industrial revolution now have a strategic positioning in attracting tourist visits. Because the film is able to exert a powerful influence on tourist visits, the Ministry of Tourism and Creative Economy then carries out a program that closely targets millennials as a tourist market target with the slogan 'instagramable'. Herein lies the power of film in attracting tourist visits that can be a solution for all tourist areas in Indonesia, especially for Rumah Galuh Village. At the beginning of the pioneering natural tourism in this village, the film had an extraordinary impact on the number of tourist visits. In 2016 until now, the number of tourist visits has increasingly declined. Based on these problems, research on making tourist films as promotional media is expected to be a useful breakthrough. This study uses the science of phenomenology, participant observation techniques, with data analysis: (1) data reduction; (2) data presentation; and (3) drawing conclusions / verification. The making of tourism films in this study uses 2 theories, a secondary theory, namely: the theory of film making with 3 working indicators: pre-production, production and post-production of films, while the primary theory is: film theory as a tourism promotion media with 4 working indicators: color, features, properties and ratios. The results of the application of the seven working indicators of the theory produce a true tourism film as a tourism promotion media. For our next research we recommend the effect or impact caused by the tourist film on the flow of tourist visits to these tourist destinations.
\end{abstract}

Keywords: Tourism Films Making, Tourism Films as Promotional Media. 


\section{Pendahuluan}

Film dan pariwisata di masa revolusi industri 4.0 saat ini memiliki positioning yang strategis dalam memimpin segmen pasar wisata. Hal ini sesuai dengan penelitian Hudson (2005) yang menemukan bahwa film dan arus kunjungan wisatawan memiliki hubungan yang sangat mempengaruhi:

Tabel 1. Dampak Film Terhadap Kunjungan Wisata

\begin{tabular}{|c|c|c|}
\hline Film / TV Series & Location & Impact \\
\hline Braveheart & Wallace Monument & $\begin{array}{l}300 \% \text { increase in visitors year after } \\
\text { release }\end{array}$ \\
\hline Dances with Wolves & Fort Hayes, Kansas & $\begin{array}{l}25 \% \text { increase compared with } 7 \% \text { for } 4 \\
\text { years before }\end{array}$ \\
\hline Close Encounters of the Third Kind & Devils Tower, Wyoming & $\begin{array}{l}75 \% \text { increase in } 1975,20 \% \text { visit now } \\
\text { because of the film }\end{array}$ \\
\hline Field of Dreams & Iowa & $35 \%$ visit in 1991 , steady rise \\
\hline Dallas & Southfork Ranch, Dallas & 500,000 visitors per year \\
\hline Lord of the Rings & New Zealand & $\begin{array}{l}10 \% \text { increase every year } 1998 \text { to } 2003 \\
\text { from UK }\end{array}$ \\
\hline Steel Magnolias & Louisiana & $48 \%$ increase year after release \\
\hline Last of the Mohicans & Chimney Rock Park, North Carolina & $25 \%$ increase year after release \\
\hline Mission: Impossible 2 & National parks, Sydney & $200 \%$ increase in 2000 \\
\hline Harry Potter & Various U.K locations & All locations - increase of $50 \%+$ \\
\hline Gorillas in the Mist & Rwanda & $20 \%$ increase in 1998 \\
\hline The Beach & Thailand & $22 \%$ increase - youth market 2000 \\
\hline Four Weddings and a Funeral & $\begin{array}{l}\text { The Crown Hotel, Amersham, } \\
\text { England }\end{array}$ & Fully booked for at least 3 years \\
\hline Saving Private Ryan & Normandy, France & $40 \%$ increase - American tourists \\
\hline Pride and Prejudice & Lyme Park, Cheshire, U.K & $150 \%$ increase in visitors \\
\hline Troy & Canakkale, Turkey & $73 \%$ increase in tourism \\
\hline Captains Corelli's Mandolin & Cephalonai, Greece & $50 \%$ increase over 3 years \\
\hline
\end{tabular}

Sumber: Hudson, S., Ritchie, J. B. (2005)

Gambar tabel tersebut menerangkan bahwa film dapat menjadi faktor utama meningkatnya jumlah kunjungan wisata ke suatu daerah. Walaupun penelitian tersebut sudah lama dilakukan namun pendapat tersebut diperkuat oleh Juškelytė (2016:54) yang menyatakan: walaupun film memiliki kekuatan dalam menarik arus kunjungan wisatawan, namun film tidak boleh hanya dipandang sebagai alat promosi saja, film dapat menjadi fungsi yang vital untuk membentuk citra destinasi wisata. Pergerakan revolusi industri 4.0 juga mempengaruhi pergerakan kepariwisataan di negara berkembang khususnya Indonesia. Perubahan tersebut terwujud dalam peningkatan kualitas sumber daya manusia (SDM), yang menjadi 
cikal bakal diadakannya Rakornas Pariwisata I Tahun 2019 dengan judul Wonderful Indonesia Digital Tourism (WIDT) 4.0 Transforming Tourism Human Resources to Win The Global Competition in The Industry 4.0 Era. Hal ini dilatarbelakangi karena terjadinya perubahan besar pada prilaku wisatawan yang umumnya menginginkan kemudahan dan kecepatan dalam: akses informasi dan service. Wisatawan inilah yang kemudian disebut sebagai wisatawan milenial, dengan cirinya yang: mobile, personal, serta interaktif (Suryajaya, 2018). Perubahan dan dampak revolusi industri 4.0 tersebut diharapkan dapat menyentuh hingga lini desa sebagai elemen terkecil wilayah negara. Dari prihal dan peluang tersebut maka Rencana Strategis Pengembangan Destinasi dan Industri Pariwisata Kementerian Pariwisata Tahun 2015-2019 dan Rencana Strategis Dinas Kebudayaan dan Pariwisata Provinsi Sumatera Utara diciptakan untuk memberdayakan sektor-sektor hulu yaitu desa melalui Program Pengembangan Wisata berbasis desa dengan capaian target: 1) Keterlibatan masyarakat lokal 2) Micro Small and Medium Enterpreneurship 3) Pemerataan pembangunan melalui pariwisata. Peneliti kemudian tertarik untuk mengangkat tema pembuatan film wisata. Dimana di dalam ide ini, ketiga elemen di atas dapat difasilitasi fungsi dan keberadaannya.

Di dalam film dan kepariwisataan, keterlibatan masyarakat lokal pasti dibutuhkan, konteks wirausaha kecil dan menengah difasilitasi karena yang akan dilakukan nantinya adalah mempromosikan produk wisata yang mereka miliki, dan terakhir pemerataan pembangunan pariwisata juga dapat tercapai apabila tingkat kunjungan wisata semakin meningkat terutama untuk Desa Rumah Galuh. Pemilihan Desa Rumah Galuh sebagai lokasi penelitian karena destinasi ini memiliki pengalaman yang erat antara film dan pariwisata. Desa Rumah Galuh mulai dikenal saat salah satu program TV nasional (My Trip My Adventure, Trans TV) melakukan shoting film wisata ke Desa Rumah Galuh. Dampak kunjungan tersebut adalah terjadinya peningkatan kunjungan yang signifikan hingga 2000-5000 orang per bulannya (tahun 2012-2014). 
Di tahun 2016 penurunan kunjungan wisata ke Desa Rumah Galuh terjadi secara dramatis yaitu 200 orang per bulannya dan terus menunjukkan penurunan. Ini merupakan titik terendah kunjungan wisata hingga saat ini. Fenomena tersebut terjadi karena banyak terjadi pemberhentian dan pemerasan oleh oknum-oknum tidak bertanggung jawab kepada wisatawan yang ingin berwisata ke Desa Rumah Galuh, hingga beberapa kejadian bencana alam yaitu banjir bandang dan kematian (tenggelam) yang terjadi di lokasi. Di tahun 2018, masyarakat mulai menunjukkan kepeduliannya dengan meminimalisir aktifitas negatif yang selama ini berlangsung di lokasi wisata.

Penurunan kunjungan wisata membuat masyarakat Desa Rumah Galuh beradaptasi dalam menjaga aktifitas wisata di desa mereka. Hal yang mereka perlukan saat ini adalah mempromosikan kembali aktifitas wisata yang aman, tertib, bersih, sejuk, indah, ramah tamah dan kenangan yang terdapat di Desa Rumah Galuh. Model media promosi dalam bentuk film adalah model yang tepat saat ini. Walaupun ada sebuah pertanyaan yang muncul yaitu: mengapa media promosi film dibutuhkan oleh masyarakat Desa Rumah Galuh? jawabannya telah tertulis di paragraf sebelumnya, dimana film-lah yang pernah mendongkrak popularitas destinasi wisata di desa ini (kunjungan My Trip My Adventure). Dari pengalaman tersebutlah, penelitian ini berusaha untuk menemukan atau melaksanakan suatu konsep film dengan unsur ilmu pariwisata yang dapat diterapkan di Desa Rumah Galuh Kabupaten Langkat sehingga dapat menjadi alat bagi stakeholder baik untuk tujuan promosi ataupun digunakan sebagai format uji lomba film wisata yang saat ini gencar dilakukan oleh berbagai komponen masyarakat terutama Pemerintah sendiri. 


\section{Teori}

\section{Pengertian Film Dokumenter}

Secara garis besar, film dapat diklasifikasikan berdasarkan genre dan tipe film. Terkait genre film, film dokumenter memiliki 12 genre, yaitu: laporan perjalanan, sejarah, potret/biografi, nostalgia, rekonstruksi, investigasi, perbandingan dan kontradiksi, ilmu pengetahuan, buku harian, musik, association picture story, dan dokudrama (Prastisa, 2008). Terkait dengan penelitian ini, film yang akan diciptakan bergenre laporan perjalanan. Istilah atau penamaan yang sering digunakan untuk jenis dokumenter ini adalah travelvlog, travel film, dan travel documentary. Setelah genre, Terdapat 5 tipe film dokumenter menurut Prastisa (2008) yaitu: tipe expository, tipe observational, tipe interactive, tipe reflexive, tipe performative, tipe poetic, namun yang menjadi kajian dalam penelitian ini adalah tipe observational. Menurut Prastisa (2008) film dokumenter observational adalah pembuat film menolak untuk mengintervensi objek dan peristiwanya. Mereka berusaha untuk netral dan tidak menghakimi subjek atau peristiwanya. Tipe ini juga menolak menggunakan narasi atau komentar dari luar ruang cerita. Penekanannya adalah untuk memaparkan potongan kehidupan manusia secara akurat atau mempertunjukkan gambaran kehidupan manusia secara langsung. Tipe inilah yang akan digunakan di dalam penelitian ini.

Dalam pembuatan film perjalanan terdapat 3 hal yang menjadi hal penting yaitu: pra-produksi film, produksi dan pasca-produksi. Adapun uraiannya yaitu: pra-produksi film: dimulai dari (1) perancangan konsep film, (2) penentuan lokasi film, (3) penentuan kegiatan perjalanan, (4) penentuan alat rekam dan alat editing film, (6) persiapan skenario film perjalanan, (7) persiapan mise-en-scene dan (8) persiapan distribusi film perjalanan. Setelah pra-produksi maka dilakukanlah produksi dan pasca-produksi film. 


\section{Pengertian Pariwisata}

Dalam UU No 10 Tahun 2009, Pariwisata adalah berbagai macam kegiatan wisata dan didukung berbagai fasilitas serta layanan yang disediakan oleh masyarakat, pengusaha, Pemerintah, dan Pemerintah Daerah. Teori tersebut memiliki Indikator primer atau utama yaitu kegiatan wisata. Terkait pembuatan film wisata nantinya difokuskan kepada pembuatan film kegiatan wisata yang ada di Desa Rumah Galuh.

\section{Pengertian Film Wisata sebagai Media Promosi}

Menurut Hasan (2015: 259) media promosi pariwisata merupakan bagian teknis dari bauran promosi pariwisata seperti periklanan, promosi penjualan dll. Media promosi memiliki ragam seperti: brosur, spanduk, foto, banner hingga film. Terkait dengan penelitian ini yang dibahas adalah film. Terkait dengan media promosi terdapat 2 tindakan yang akan dilakukan sesuai dengan teori ini, yaitu pembuatan film promosi wisata desa yang kemudian akan dipublish di instagram. Film biasanya berdurasi maksimal 5 menit, clip dibuat secara singkat, padat, jelas dan mengena kepada wisatawan yang menonton. Menurut Hasan (2015: 266) terdapat hal penting yang harus diperhatikan terkait dengan isi iklan wisata yang menggunakan film sebagai media promosinya, yaitu: (1) warna ataupun gambar yang diproyeksikan dari film dirancang untuk menarik perhatian wisatawan; (2) tampilkan fitur yang dapat memperkuat keunikan citra destinasi wisata; (3) tunjukkan sifat multi dimensi destinasi (aneka kegiatan apa saja yang dapat dilakukan di daya tarik tersebut); (4) gunakan rasio 54\% tampilan gambar dan 46\% informasi. 


\section{Metode}

Jenis penelitian ini adalah penelitian kualitatif, menggunakan ilmu fenomenologi. Subjek penelitian dalam penelitian ini adalah major stakeholder yaitu pemangku kepentingan yang memiliki kepentingan langsung di Desa Rumah Galuh seperti: pengelola pemandian alam Desa Rumah Galuh, tokoh masyarakat, perangkat desa, guide, pelaku film dan Dinas Pariwisata Kabupaten Langkat. Teknik pengambilan sampel dalam penelitian adalah snowball sampling. Sumber data dalam penelitian ini ada 2 yaitu: 1) sumber data primer (wawancara dengan informan dan pustaka), dan 2) sumber data sekunder (informasi digital/ebook, buku, undangundang, film/foto). Instrumen Penelitian ini menggunaan 2 bentuk: menggunakan pedoman wawancara dan buku panduan format film. Teknik observasi menggunakan observasi partisipan. Teknik analisis data dalam penelitian ini menggunakan model Miles dan Huberman dalam Yusuf (2016:407), seperti: reduksi data, display data, penarikan kesimpulan/verifikasi.

\section{Hasil dan Pembahasan}

Dalam pembuatan film wisata sebagai media promosi pariwisata di Desa Rumah Galuh Kabupaten Langkat, memiliki beberapa hal yang harus dipertimbangkan, yaitu 1) proses pembuatan film wisata itu sendiri dan 2) validasi yang membuktikan bahwa film wisata yang dibuat memang benar sebuah film wisata yang diperuntukkan sebagai media promosi. Adapun proses pembuatan film wisata mencangkup: pra-produksi, produksi hingga pasca-produksi; sedangkan untuk validasi film wisata sebagai media promosi mencangkup: warna atau gambar film, fitur memperkuat keunikan citra destinasi wisata, bersifat multi dimensi destinasi dan rasio 54\% tampilan gambar dan $46 \%$ informasi. Adapun uraian lengkap tersebut ditulis sebagai berikut: 


\section{Proses Pembuatan film Wisata}

Terdapat 3 hal utama dalam proses pembuatan film wisata di Desa Rumah Galuh yaitu pra-produksi film, produksi dan pasca-produksi. Adapun uraian lengkapnya dijelaskan sebagai berikut:

\section{Pra-Produksi Film Wisata}

Pra-produksi film wisata di Desa Rumah Galuh dimulai dari (1) perancangan konsep film wisata, (2) penentuan lokasi film wisata, (3) penentuan kegiatan wisata, (4) penentuan alat rekam dan alat editing film, (6) persiapan skenario film wisata, dan (7) persiapan mise-en-scene dan (8) persiapan distribusi film wisata.

\section{Perancangan Konsep Film Wisata}

Adapun rencana konsep film wisata yang dirancang dalam aktivitas shoting merupakan kegiatan wisata yang terdapat di Desa Rumah Galuh. Kegiatan wisata yang terdapat di Desa Rumah Galuh merupakan jenis adventure tourism ataupun wisata petualang. Dari pemahaman ini kemudian dapat disimpulkan bahwa konsep film wisata yang akan dibuat nantinya di Desa Rumah Galuh adalah film promosi wisata adventure. Setelah menentukan konsep film wisata yang terdapat di Desa Rumah Galuh, kemudian peneliti menganalisa dan menentukan lokasi tempat pembuatan film dengan melakukan survei ke lokasi. Berdasarkan wawancara yang telah dilakukan antar stakeholder dan peneliti, kemudian disepakati 4 lokasi utama yang akan dilakukan pengambilan film.

\section{Penentuan Lokasi Film Wisata}

Setelah merancang konsep film yang akan diciptakan di lokasi, berikutnya yang harus ditentukan adalah lokasi film wisata. tim harus melakukan inventarisasi produk wisata alam yang terdapat di destinasi wisata. Berdasarkan inventarisasi produk wisata alam yang terdapat di Desa Rumah Galuh terdapat 4 daya Tarik 
wisata yang ditentukan untuk pengambilan film wisata yaitu: Kolam Abadi, Air Terjun Tero-Tero, Air Terjun Tongkat dan Air Terjun Lau Berte.

\section{Penentuan Kegiatan Wisata}

Kegiatan wisata yang terdapat di lokasi terdiri dari dua jenis kegiatan yaitu kegiatan primer dan kegiatan sekunder. Kegiatan primer di lokasi wisata ini adalah jungle tracking (berjalan menyusuri hutan), melihat air terjun dan body rafting (kegiatan mengikuti dan melawan arus sungai dengan menggunakan tubuh kita sendiri). Kegiatan sekunder di lokasi wisata ini seperti: melihat flora langka di hutan (bunga bangkai: Amorphophallus Titanum Becc), camping/berkemah, berenang dan minum air nira yang langsung di ambil dari petani lokal.

\section{Penentuan Alat Rekam dan Alat Editing Film}

Penentuan alat rekam dan alat editing sangat menentukan kualitas yang dihasilkan dari film wisata yang akan diciptakan untuk Desa Rumah Galuh. Perencanaan terhadap hal ini urgent dilakukan karena dari alat ini nantinya, pembuat film mengetahui keterbatasan dalam pengambilan film saat berada dilokasi. Apabila beranjak dari kekuatan lokasi maka alat yang dibutuhkan harus mampu menangkap situasi di dalam air, darat dan udara. Dari hal tersebut kemudian tim harus menentukan alat rekam, alat editing dan alat pendukung : (1) Xiaomi action cam: fungsi alat ini dalam pembuatan film wisata yaitu ditujukan untuk merekam di dalam air; (2) Panasonic lumix G7: fungsi alat ini dalam pembuatan film wisata yaitu ditujukan untuk merekam dengan kualitas yang tinggi dalam pengambilan video darat; (3) Dji Osmo X3: fungsi alat ini dalam pembuatan film wisata ditujukan di darat untuk merekam keadaan ekstrim, seperti: pada saat berjalan cepat dan berlari; (4) Dji Phantom 4: fungsi alat ini dalam pembuatan film wisata yaitu ditujukan untuk merekam dari udara; (5) Filter lensa: fungsi alat ini dalam pembuatan film wisata yaitu sebagai alat pendukung pembuatan film yang ditujukan untuk menyaring cahaya matahari yang masuk ke sensor kamera; (6) 
Aplikasi Adobe Premiere Pro 2019, Laptop Asus ROG dan Izotope RX6: adalah sebuah aplikasi dan alat editing yang ditujukan untuk pengolahan video menjadi film.

\section{Persiapan Skenario Film Wisata}

Skenario film wisata: Film wisata ini mengkemas berbagai informasi mengenai kegiatan wisata yang terdapat di Desa Rumah Galuh. Di dalam film ini, stakeholder wisata Desa Rumah Galuh juga memberikan gambaran untuk menumbuhkan motivasi berkunjung kepada calon wisatawan dengan menyajikan 2 lokasi wisata utama seperti Kolam Abadi dan Air Terjun Tero-Tero dan 2 lokasi wisata yang jarang dikunjungi seperti Air Terjun Tongkat dan Air Terjun Lau Berte dengan pesona keindahan alam luar biasa. Lokasi ini dapat menjadi bucket list bagi wisatawan yang ingin mendapat sensasi pengalaman berjalan di hutan (jungle tracking), mengarungi sungai yang jernih dengan hanya menggunakan pelampung (body rafting), melihat dan berendam dibawah air terjun dan lompat dari bebatuan alami ke dasar sungai untuk menikmati petualangan yang menegangkan di lokasi ini. Kuantitas dan kualitas lokasi wisata yang dikemas di dalam film wisata ini merupakan sebuah potensi yang jarang dimiliki oleh desa-desa lain di Sumatera Utara. Rencana skenario yang bersifat general juga akan digunakan: di sampul belakang DVD yang akan diberikan kepada stakeholder dan di caption promosi pada media sosial seperti instagram dan kepada Dinas Pariwisata Kabupaten Langkat.

\section{Persiapan Mise-en-scene}

Mise-en-scene memiliki posisi urgent dalam pembuatan film wisata ini, karena mencakup latar, tata cahaya, kostum, akting pemain dan komposisi. Untuk latar, pengambilan film hanya berfokus pada kealamian lokasi wisata. Dengan kata lain, untuk membuat film dengan aktivitas wisata yang bernuansa petualang yang menekankan pada ke-autentikan lokasi, maka latar pengambilan film diusahakan tampil apa adanya. Apabila latar dirubah dikhawatirkan akan memberikan pesan 
yang keliru kepada calon wisatawan yang menonton nantinya. Hal ini berlaku juga untuk pengaturan tata cahaya, kustom pelaku dan akting pemain. Dilandaskan bahwa film ini berjenis film dokumenter observational, maka setting yang diaplikasikan di lapangan adalah tampilan yang sebenar-benarnya dengan seminimal mungkin pengaturan tambahan di lapangan.

\section{Persiapan Distribusi Film Wisata}

Film wisata rencananya akan di-publish di media sosial yang memiliki pengikut atau follower yang besar seperti medantalk, lingkar sumut dan anak usu. Media sosial ini dipilih karena target calon wisatawan yang diharapkan diprioritaskan wisatawan lokal yang berasal dari Sumatera Utara terkhususnya Kota Medan.

\section{Produksi Film Wisata}

Produksi film wisata yang dimaksud adalah aplikasi atau penerapan dari seluruh perencanaan awal pembuatan film yang telah ditetapkan pada saat praproduksi. Adapun produksi film wisata pada saat di lapangan seperti: pengecekan kembali kesesuaian shoting film dengan konsep film wisata, pengambilan gambar dari lokasi film wisata yang telah ditentukan, shoting yang difokuskan pada kegiatan wisata, penggunaan Alat Rekam pada saat berada di lokasi wisata, penerapan Skenario Film Wisata di lokasi wisata, dan penerapan mise-en-scene. Indikator kerja produksi film wisata, seperti: 
1.Shot dilakukan secara:

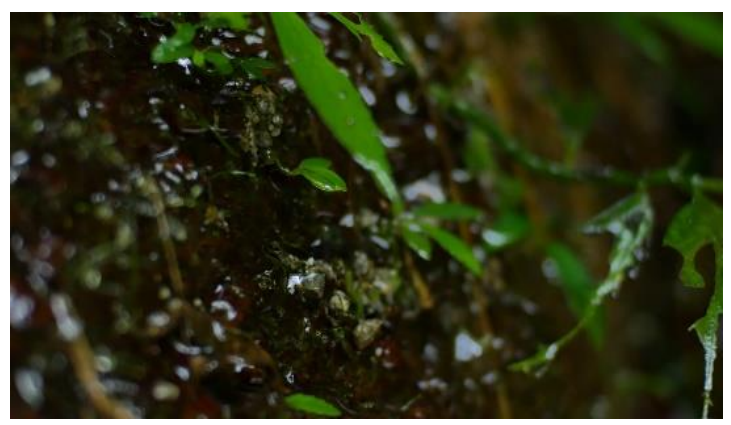

Gambar 1. Extreme Close Up Sumber: Dokumentasi Pribadi

Tipe shot dari gambar 1 ini kami pakai sebagai pelengkap film. Maksud dari pengambilan ini adalah agar calon wisatawan dapat melihat detail kesegaran dan kealamian dari 4 daya tarik wisata ini. Berdasarkan hasil wawancara, tipe ini tidak memberikan pengaruh yang besar bagi calon wisatawan karena ketika berkunjung para wisatawan melihat lokasi secara wide atau luas, jarang ada wisatawan melihat lokasi wisata secara detail seperti ini, oleh karena itu shot tipe ini hanya sekali dilakukan.

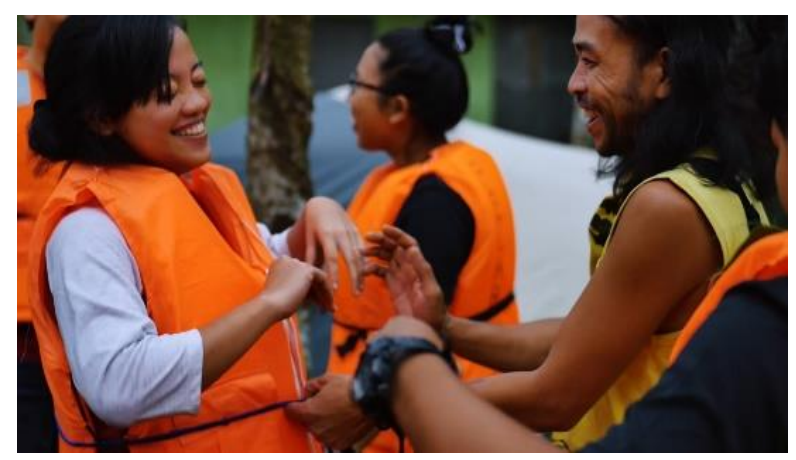

Gambar 2. Medium Shot Sumber: Dokumentasi Pribadi

Tipe shot dari gambar 2 digunakan untuk menggambarkan kedekatan pengunjung dan pemandu, sehingga calon wisatawan tidak perlu khawatir akan keselamatan dan kenyamanan ketika berkunjung. Berdasarkan hasil wawancara, tipe ini memberikan pengaruh yang sangat besar bagi wisatawan dalam membuat 
keputusan berkunjung. Dalam adegan ini pemandu memberikan pesan yang tersirat bahwa: setiap wisatawan yang berwisata ke lokasi ini pasti akan mendapat pelayanan yang ramah, tanggap dan humanis dari stakeholder-nya.

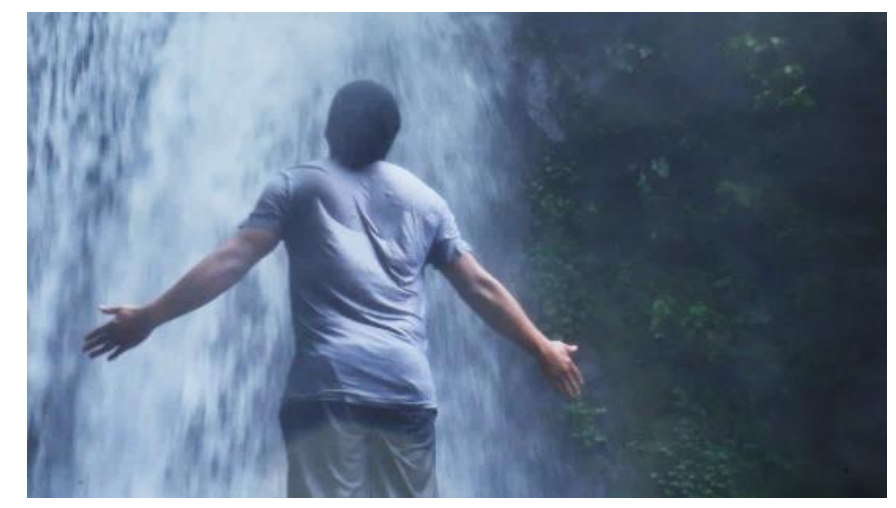

Gambar 3. Medium Long Shot

Sumber: Dokumentasi Pribadi

Tipe shot dari gambar 3 digunakan untuk menggambarkan kedekatan manusia dan alamnya. Tipe ini digunakan hampir 40\% dalam proses produksi. Tipe ini memberikan penekanan kepada penonton bahwa ketika mengunjungi lokasi ini, pengunjung dapat merasakan perasaan teduh dan damai. Berdasarkan hasil wawancara, tipe ini memberikan pengaruh yang sangat besar bagi wisatawan dalam membuat keputusan berkunjung, dengan 2 pendapat, yaitu: 1) ingin merasakan sensasi yang dirasakan seperti di dalam film wisata; 2) ingin mendapat shot yang sama seperti di dalam film sehingga dapat dipublish di media sosial wisatawan.

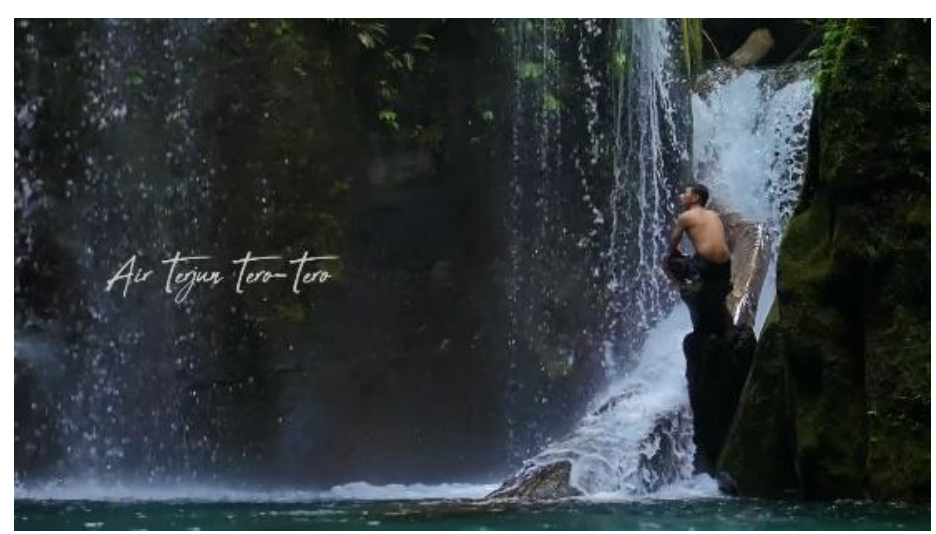

Gambar 4. Long Shot Sumber: Dokumentasi Pribadi 
Tipe shot dari gambar 4 digunakan untuk mengkolaborasi perasaan aktor dan alam disekitarnya. Tipe shot ini merupakan tipe shot yang hampir menampilkan keseluruhan lokasi wisata. Tipe ini memberikan informasi kepada penonton mengenai suasana yang terdapat di lokasi wisata ini. Berdasarkan hasil wawancara, tipe ini memberikan pengaruh besar terutama wisatawan yang berencana datang berkelompok. Tipe ini memberikan gambaran kepada wisatawan mengenai tampilan lokasi wisata secara dekat.

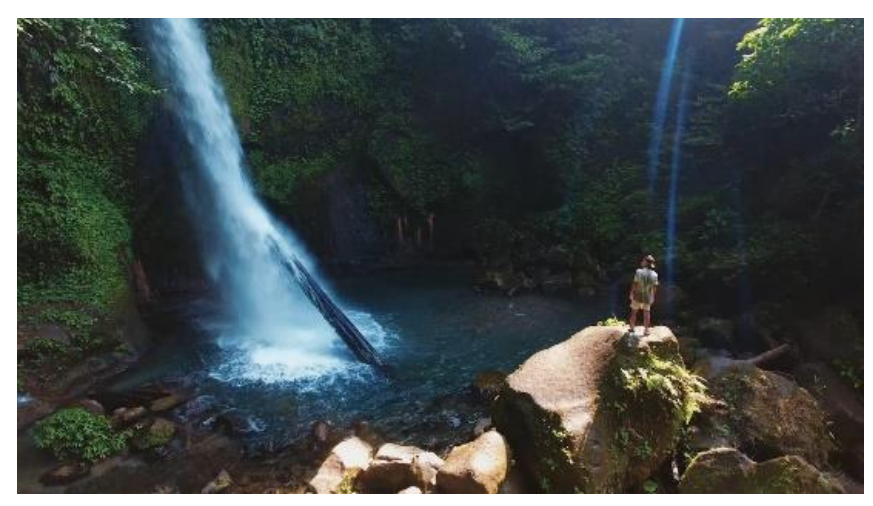

Gambar 5. Estabilishing Shot

Sumber: Dokumentasi Pribadi

Tipe shot dari gambar 5 digunakan untuk menampilkan secara lebih jelas lokasi wisata yang sebenar-benarnya yang akan dikunjungi. Tipe ini memberikan informasi tanpa mengurang-ngurangi apa yang dipandang oleh mata, baik ketika menonton ataupun mengunjungi langsung lokasi wisata, sehingga calon wisatawan tidak miss-persepsi terhadap lokasi yang dikunjungi. tipe ini memberikan pengaruh yang sangat besar bagi wisatawan dalam membuat keputusan berkunjung karena calon wisatawan mengetahui secara lebih pasti keunikan dari wisata yang dituju. Tipe ini paling banyak digunakan di dalam film untuk menunjukkan lokasi wisata secara lebih sempurna. 
2.Angle dilakukan secara:

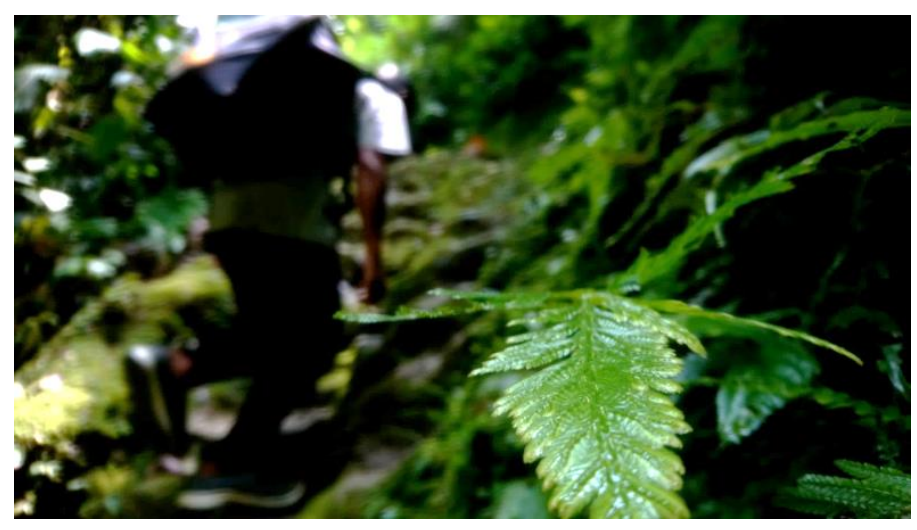

Gambar 6. Frog eye level

Sumber: Dokumentasi Pribadi

Angle shot dari gambar 6 ini digunakan untuk menjelaskan kepada penonton mengenai akses menuju ke lokasi wisata dari pos pemandu yang menanjak dan menurun, sehingga wisatawan memahami bagaimana jalur alam menuju 4 daya tarik wisata tersebut.
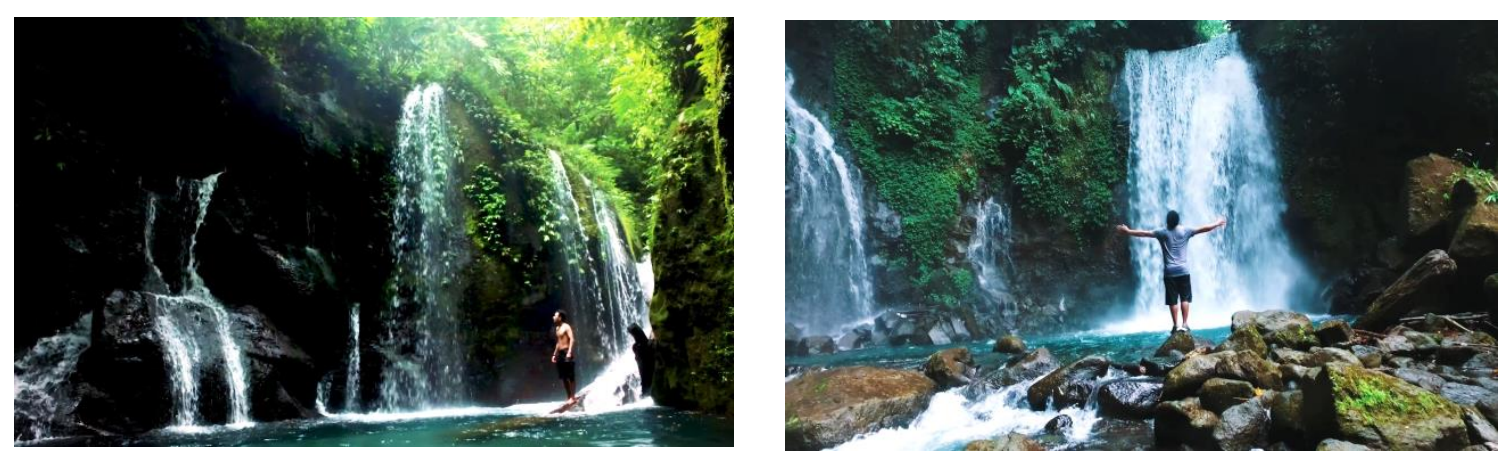

Gambar 7. Low Angle

Sumber: Dokumentasi Pribadi

Angle shot dari gambar 7 ini digunakan untuk menjelaskan kepada penonton mengenai tampilan lokasi wisata secara penuh. Angle ini digunakan 2 kali di dalam film untuk mengungkap kepada calon wisatawan tampilan daya tarik wisata secara menyeluruh. 

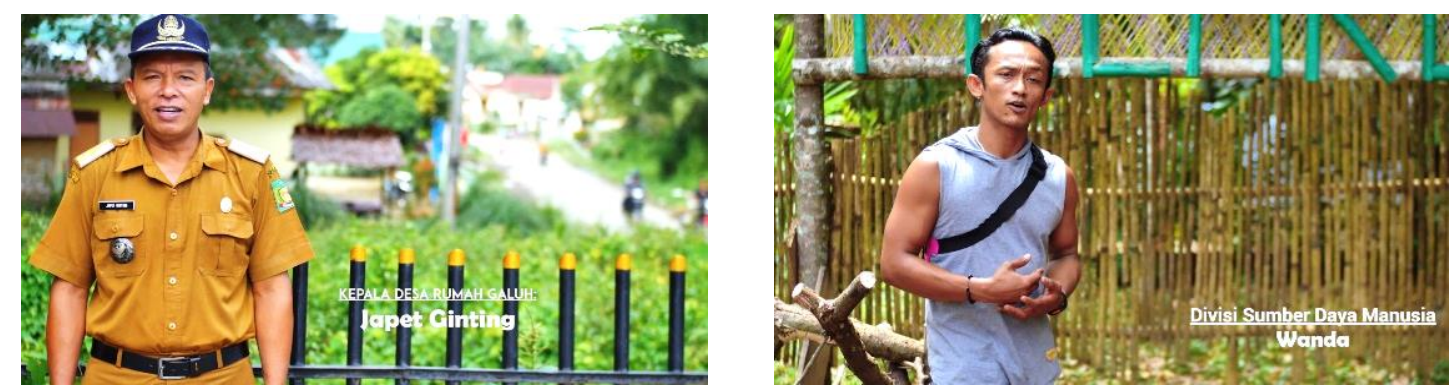

Gambar 8. Eye Level

Sumber: Dokumentasi Pribadi

Angle shot dari gambar 8 ini digunakan untuk menunjukkan stakeholder yang terlibat dan bertanggungjawab di lokasi wisata kepada calon wisatawan. Angle ini digunakan untuk memberikan keterangan ataupun deskripsi destinasi wisata.
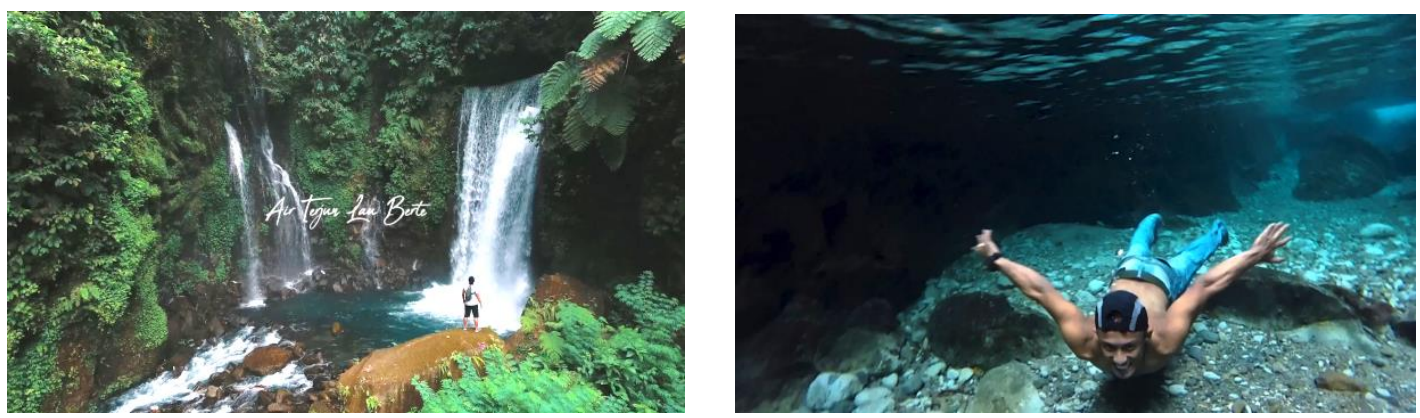

Gambar 9. High Angle

Sumber: Dokumentasi Pribadi

Angle shot dari gambar 9 ini adalah jenis angle yang sangat kami prioritaskan di dalam produksi film wisata Desa Rumah Galuh. Dikarenakan film wisata memiliki maksud yaitu 'reveal' atau mengungkapkan / menyingkapkan / membeberkan / membuka potensi ke 4 daya tarik wisata secara penuh di dalam film wisata. 

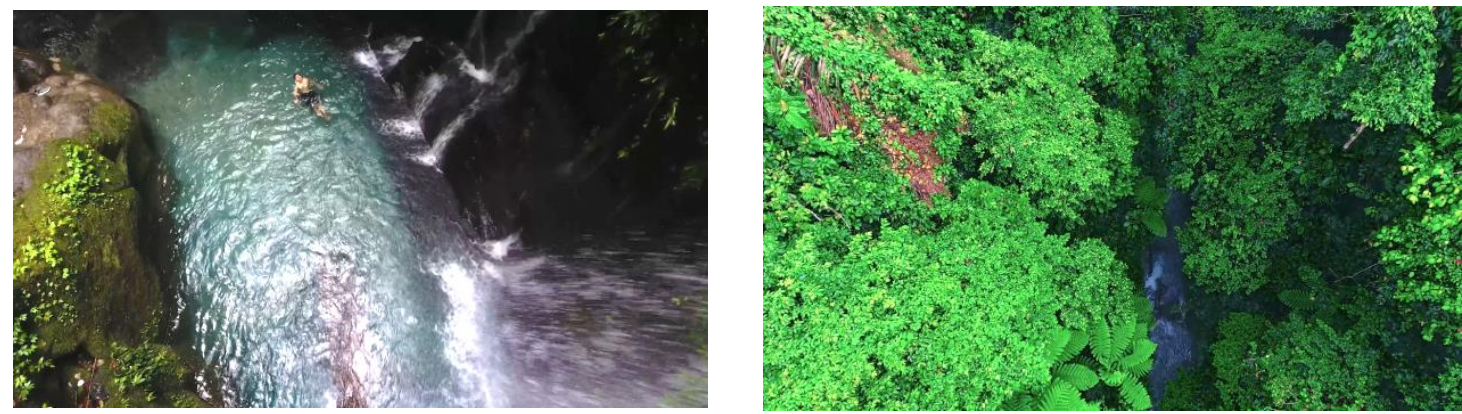

Gambar 10. Bird Angle

Sumber: Dokumentasi Pribadi

Angle shot dari gambar 10 ini sangat sulit dipakai di lokasi ini karena dengan lebar sungai yang kecil (maksimal 4 meter), pemandangan dari atas, tidak mampu menunjukkan keindahan sungai ini. Namun metode ini tetap dipakai untuk memaksimalkan berbagai macam sudut perekaman.

\section{Pasca-Produksi Film Wisata}

Pasca-produksi fim wisata merupakan tahap akhir sebelum akhirnya film wisata di distribusikan secara luas. Pasca-produksi pembuatan film wisata mencangkup 2 aspek yaitu video processing dan audio proccesing. Untuk video processing hal yang dilakukan adalah:

1. Logging, di proses ini editor memasukkan seluruh hasil shot kedalam folder yang sebelumnya telah dipisah berdasarkan waktu dan alat rekam

2. Digitizing, data yang telah dipilih dan tersusun di dalam folder kemudian dimaksukkan ke dalam adobe premiere pro 2019 untuk diolah.

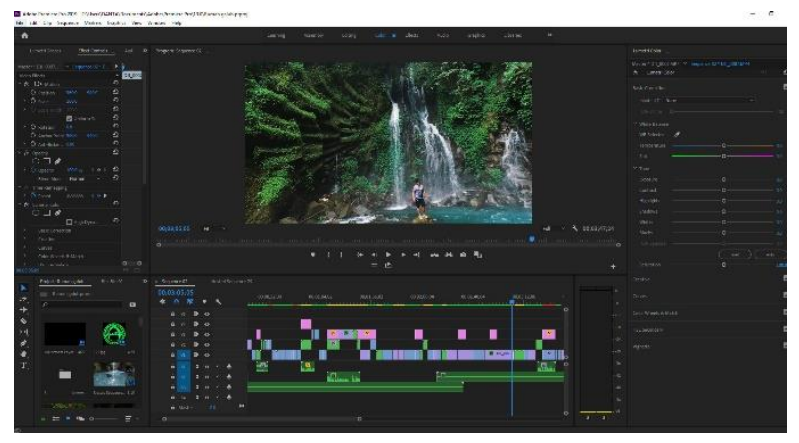

Gambar 11. Proses Pasca Produksi Video

Sumber: Dokumentasi Pribadi 
3. Offline editing, skenario yang telah dibaca oleh stakeholder kemudian dicocokkan dengan video-video yang memiliki keterkaitan dengan tema film wisata.

4. Online editing, dalam hal ini editor kemudian melakukan proses untuk memperhalus hasil dari offline editing.

5. Mixing, terdapat dua tindakan yang harus dilakukan yaitu mengatur tinggi rendah suara musik dengan suara aktor yang berperan dan menyesuaikan dengan beat musik yang digunakan.

Untuk audio processing hal yang dilakukan adalah memilimalisir noise yang timbul dari lingkungan alam Desa Rumah Galuh:

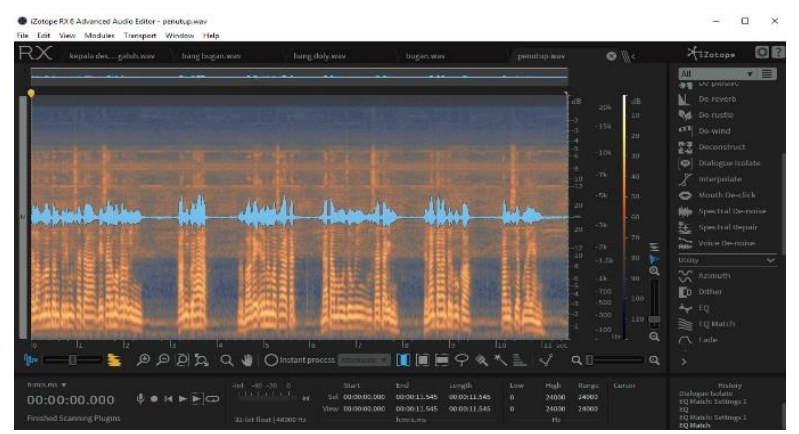

Gambar 12. Proses Pasca Produksi Audio

Sumber: Dokumentasi Pribadi

Bagian prioritas dari aplikasi yang sering digunakan di audio processing film wisata Desa Rumah galuh ini adalah voice de-noise, dialogue isolate dan EQ

\section{Validasi Film Wisata Sebagai Media Promosi}

Validasi merupakan kegiatan yang dilakukan untuk menguji apakah film wisata yang telah diciptakan sudah tepat atau belum untuk kepentingan media promosi. Untuk menguji hasil film wisata sebagai media promosi maka dilakukan sebuah validasi data yang dilandasi oleh teori Hasan (2015). Teori Hasan (2015) memiliki 4 indikator kerja yang dipakai oleh peneliti dan stakeholder pariwisata dalam me-review film wisata yang telah diciptakan. Stakeholder yang dimaksudkan adalah pemilik pos wisata, guide lokal, pelaku film, wisatawan dan Dinas Pariwisata Kabupaten 
Langkat. 4 indikator kerja di dalam teori Hasan (2015) kemudian dipakai sebagai format pengecekan film wisata. Berdasarkan hasil review didapati hasil sebagai berikut:

1. Warna ataupun gambar yang diproyeksikan dari film wisata sebagai media promosi harus dirancang untuk menarik perhatian wisatawan: indikator kerja ini kemudian di uji terhadap film wisata dengan unsur pengujinya adalah pandangan stakeholder terhadap warna film, pesan dari gambar film dan apakah film wisata sudah mampu menarik perhatian wisatawan?. Dari hasil uji tersebut diungkapkan bahwa film wisata memiliki gambar yang natural tidak dibuat-buat. Warna dari film wisata telah mampu memproyeksikan lokasi wisata dengan sebenar-benarnya dan apa adanya, tentunya dengan kondisi cuaca yang baik. Keterbatasan warna film adalah film wisata yang diciptakan kurang mampu menunjukkan kondisi sebenarnya apabila cuaca di lokasi wisata tidak mendukung. Apabila cuaca hujan, warna air menjadi agak keruh terkadang coklat seperti gambar dibawah ini:
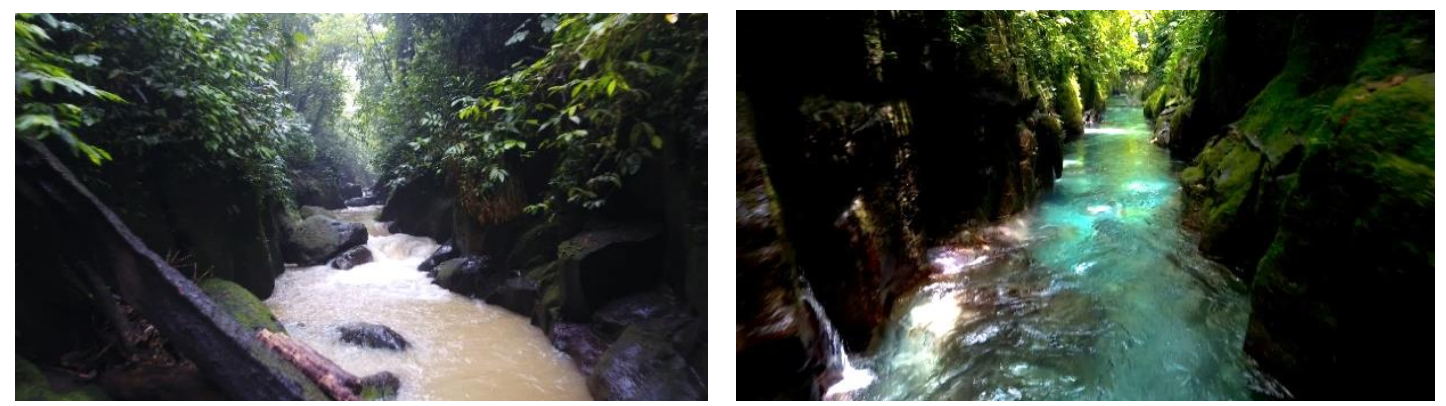

Gambar 13. Perbandingan tampilan air sungai pada

saat cuaca hujan dan cuaca kemarau

Sumber: Dokumentasi Pribadi

tentu ini kurang sesuai dengan tampilan film wisata yang disajikan sehingga dapat membuat wisatawan kecewa ketika berkunjung. Berikutnya, apakah warna atau gambar film wisata telah mampu menarik perhatian wisatawan? hasilnya adalah benar, warna film wisata yang dibuat mampu menarik 
perhatian wisatawan. Uji tersebut diambil dari feed back ataupun respon wisatawan terhadap film wisata yang telah mereka tonton. Dari 10 wisatawan yang telah menonton film wisata, keseluruhannya berpendapat bahwa warna atau gambar film wisata mampu untuk menarik minat wisatawan untuk berkunjung terutama wisatawan yang berasal dari negara malaysia.

2. Film wisata sebagai media promosi harus menampilkan fitur yang dapat memperkuat keunikan citra destinasi wisata. Penekanan dari teori ini adalah 'cara menampilkan keunikan destinasi' melalui fitur pengambilan film. Untuk mengungkap 'keunikan destinasi' maka film wisata harus mampu menangkap gambar dari berbagai macam angle dan shot. Indikator kerja ini kemudian di uji terhadap film wisata dengan unsur pengujinya adalah sudut padang shoting film. Film wisata pada umumnya hanya menggambarkan lokasi wisata dari satu angle dan shot saja. Hal ini terjadi karena pada umumnya para pembuat film hanya menggunakan DSLR ataupun kamera darat untuk shoting film wisata, sehingga keterbatasan dari alat tersebut membuat fitur dan keunikan destinasi dari berbagai sudut pandang tidak keluar di dalam film. Dikarenakan dalam pengambilan film, tim menggunakan berbagai macam alat rekam baik dari shoting dalam air, darat dan udara sehingga keunikan citra destinasi wisata dari berbagai sudut pandang mampu terlihat semua, baik dari dalam air, darat hingga udara. Dari hasil uji tersebut diungkapkan bahwa sudut pandang shoting dan angle film wisata mampu menampilkan fitur yang dapat memperkuat keunikan citra destinasi wisata indah dan alami.

3. Film wisata sebagai media promosi harus mampu menunjukkan sifat multidimensi destinasi. Indikator kerja ini kemudian di uji terhadap film wisata dengan unsur pengujinya adalah tampilan ragam aktivitas atau kegiatan wisata yang dapat dilakukan di lokasi wisata. Disinilah letak sifat multidimensi dari destinasi wisata alam ini. Pengunjung bukan datang hanya 
melihat alam yang indah, namun dapat menikmati alam itu secara langsung dengan berbagai macam aktivitas wisata kreatif yang terdapat di Desa Rumah Galuh. Respon stakeholder terhadap hal tersebut adalah film wisata mampu menunjukkan ragam kegiatan wisata seperti: jungle tracking, melihat air terjun dan body rafting.

4. Film wisata sebagai media promosi harus memiliki rasio kurang lebih $54 \%$ tampilan gambar wisata dan $46 \%$ informasi wisata. Indikator kerja ini kemudian di uji terhadap film wisata dengan unsur pengujinya adalah efektivitas dan efisiensi waktu film dalam menyampaikan informasi wisata. Tanggapan stakeholder terhadap hal tersebut adalah film wisata mampu memberikan tampilan gambar dan informasi wisata yang seimbang sehingga informasi audio visual yang disajikan tidak bias dan berbelit-belit.

Dari hasil uji empat indikator kerja teori di atas, maka dapat disimpulkan bahwa film wisata yang telah dibuat tersebut adalah benar film wisata untuk media promosi Desa Rumah Galuh Kabupaten Langkat.

\section{Kesimpulan}

Dalam pembuatan film wisata sebagai media promosi pariwisata di Desa Rumah Galuh Kabupaten Langkat, memiliki beberapa hal yang harus dipertimbangkan, yaitu 1) proses pembuatan film wisata itu sendiri dan 2) validasi yang membuktikan bahwa film wisata yang dibuat memang benar sebuah film wisata yang diperuntukkan sebagai media promosi. Adapun proses pembuatan film wisata mencangkup: pra-produksi, produksi hingga pasca produksi; hal terpenting dari ketiga indikator kerja tersebut adalah pra-produksi, karena mencangkup seluruh perencanaan teknis di daya Tarik wisata yang si shoting. Pra-produksi film wisata di Desa Rumah Galuh dimulai dari (1) perancangan konsep film wisata, (2) penentuan lokasi film wisata, (3) penentuan kegiatan, (4) fasilitas dan layanan wisata di lokasi film wisata, (5) penentuan alat rekam dan alat editing film, (6) persiapan 
skenario film wisata (sinematografi), dan (7) persiapan mise-en-scene. Ketujuh hal inilah menjadi tugas pokok yang harus dilaksanaan pada saat produksi hinga pascaproduksi film, sedangkan untuk validasi film wisata sebagai media promosi mencangkup: (1) warna atau gambar film: dimana unsur pengujinya adalah pandangan stakeholder terhadap warna dan pesan dari gambar film, hasil penelitian mengungkapkan bahwa Dari 10 wisatawan yang telah menonton film wisata, keseluruhannya berpendapat bahwa film wisata mampu untuk menarik minat wisatawan untuk berkunjung, (2) Film wisata sebagai media promosi harus menampilkan fitur yang dapat memperkuat keunikan citra destinasi wisata: dengan unsur pengujinya adalah sudut padang shoting film. Dari hasil uji tersebut diungkapkan bahwa sudut pandang shoting film wisata mampu memperkuat keunikan citra Desa Rumah Galuh sebagai destinasi wisata alam yang indah dan alami, (3) Film wisata sebagai media promosi harus mampu menunjukkan sifat multi dimensi destinasi: dengan unsur pengujinya adalah tampilan ragam aktivitas atau kegiatan wisata yang dapat dilakukan di lokasi wisata. Dari hasil uji tersebut diungkapkan dari respon stakeholder terhadap hal tersebut yaitu film wisata mampu menunjukkan ragam kegiatan wisata seperti: jungle tracking, melihat air terjun dan body rafting, (4) dan rasio 54\% tampilan gambar dan $46 \%$ informasi: dengan unsur pengujinya adalah efektivitas dan efisiensi waktu film dalam menyampaikan informasi wisata. Dari hasil uji tersebut diungkapkan dari tanggapan stakeholder terhadap hal tersebut adalah film wisata mampu memberikan tampilan gambar dan informasi wisata yang seimbang sehingga informasi audio visual yang disajikan tidak bias dan berbelit-belit. 


\section{Daftar Pustaka}

Ayawaila, Gerzon R. 2008. Dokumenter: dari ide sampai produksi. FFTV-IKJ Press. Jakarta.

Brata, Vincent Bayu Tapa. 2007. Videografi dan sinematografi praktis. Jakarta: PT. Elex Media Komputindo.

Christina, Natalia, dkk. 2017. Perancangan film dokumenter tentang perjalanan hidup pelaku hip-hop. Jurnal Desain Komunikasi Visual Adiwarna Vol 1 , 1327 | vol: | issue : |2017.

Hasan, Ali. 2015. Tourism marketing. Yogyakarta: CAPS (Center of Academic Publishing Service).

Himawan Pratista. 2008. Memahami film. Homerian Pustaka. Yogyakarta.

Hudson, S., Ritchie, J. B. (2005). Film tourism and destination marketing: the case of captain corelli's mandolin. Journal of Vacation Marketing, Vol. 12 (3), p. 256268.

Irawan, Etsa Indra. 2011. Sinematografi (panduan usaha mandiri). Bandung: Yrama Widya.

Juškelytè, Donata. (2016, June). Film induced tourism: destination image formation and development. Regional Formation and Development Studies, Vol 19, No 2, 54-66. Doi: 10.15181/rfds.v19i2.1283

Nare, Amogelang Tsholofelo, Gwinyai Mercy Musikavanhu \& Simon Chiutsi. 2017. Tourism diversification in Botswana-a stakeholder perspective. African Journal of Hospitality, Tourism and Leisure, Volume 6 (3) - (2017) ISSN: 2223-814X.

Pemerintah Indonesia. 2009. Undang-Undang No. 10 Tahun 2009 tentang kepariwisataan. Kementerian Pariwisata dan Ekonomi Kreatif.

Pemerintah Indonesia. 2009. Undang-Undang Republik Indonesia Nomor 33 Tahun 2009 Tentang Perfilman. Presiden Republik Indonesia.

Pemerintah Indonesia. 2011. Peraturan Pemerintah Republik Indonesia Nomor 50 Tahun 2011 Tentang Rencana Induk Pembangunan Kepariwisataan Nasional Tahun 2010-2025. Presiden Republik Indonesia.

Pemerintah Indonesia. 2013. Rencana Strategis Dinas Kebudayaan dan Pariwisata Provinsi Sumatera Utara Tahun 2013-2018. Dinas Kebudayaan Dan Pariwisata Provinsi Sumatera Utara.

Pemerintah Indonesia. 2015. Laporan Akuntabilitas Kinerja Kementerian Pariwisata tahun 2015. Kementerian Pariwisata dan Ekonomi Kreatif. 
Pemerintah Indonesia. 2015. Rencana Strategis Pengembangan Destinasi dan Industri Pariwisata Kementerian Pariwisata Tahun 2015-2019. Kementerian Pariwisata dan Ekonomi Kreatif.

Pemerintah Indonesia. 2017. Peraturan Menteri Dalam Negeri Republik Indonesia Nomor 3 Tahun 2017. Kementerian Dalam Negeri dan Pemerintahan Daerah.

Perkasa, Huda dan Sayatman. 2015. Perancangan film dokumenter - kawasan purbakala gunung penanggungan. Jurnal Sains Dan Seni ITS Vol. 5, No.2, (2015) 2337-3520 (2301-928X Print).

Polianskaia, Anna. 2017. Film tourism responses to the tourist's expectations - new challenges. SEA - Practical Application of Science Volume IV, Issue 1 (10) / 2016.

Sarosa, Samiaji. 2017. Penelitian kualitatif (dasar-dasar) - edisi kedua. Jakarta: Penerbit Indeks.

Semedhi, Bambang. 2011. Sinematografi-videografi suatu pengantar. Bogor: Penerbit Ghalia Indonesia.

Suryajaya, Minghadi. 2018. Wonderful indonesia revolusi tour \& travel digital. Jakarta: Elex Media Komputindo.

Tudor, Gabriela-Cosmina. 2017. Film Tourism - A Successful Journey For New Zealand. Cactus Tourism Journal Vol. 12, Issue 2/2015, Pages 45-53, ISSN 22473297.

Yusuf, A. Muri. 2013. Metode Penelitian (Kuantitatif, Kualitatif, Penelitian Gabungan). Jakarta: Prenadamedia Group. 


\section{Profil Penulis}

Samerdanta Sinulingga, S.ST.Par., M.Par. adalah seorang dosen di Universitas Sumatera Utara, Fakultas Ilmu Budaya, DIII Perjalanan Wisata. Beliau merupakan alumni dari Fakultas Pariwisata dan Magister Kajian Pariwisata Universitas Udayana. Di USU beliau mengajar mata kuliah Sistem Informasi Pariwisata I dan II yang berfokus pada konten seperti tulisan, foto dan pembuatan video promosi sebagai produk dari Sistem Informasi secara general.

Drs. Jhonson Pardosi, M.Si, Ph.D adalah seorang dosen di Universitas Sumatera Utara, Fakultas Ilmu Budaya, DIII Perjalanan Wisata. Beliau merupakan alumni dari Fakultas Sastra USU, Magister Kajian Budaya Universitas Udayana dan Doktor dan Pengajian Ilmu Kemanusiaan (School of Humanities) USM, Malaysia. Di USU beliau mengajar mata kuliah Pengembangan Desa Wisata yang berfokus pada strategi pengembangan dan pemasaran Desa Wisata.

Dra. Nurcahaya Bangun, M.Si adalah seorang dosen di Universitas Sumatera Utara, Fakultas Ilmu Budaya, DIII Perjalanan Wisata. Beliau merupakan alumni dari Fakultas Sastra USU dan Magister Kajian Budaya Universitas Udayana. Di USU beliau mengajar mata kuliah Bahasa Inggris Profesi Pariwisata.

Hotlan Siahaan, S.Sos., M.I.Kom adalah seorang dosen di Universitas Sumatera Utara, Fakultas Ilmu Budaya, S1 Ilmu Perpustakaan. Beliau merupakan alumni dari Ilmu Perpustakaan dan Ilmu Informasi Dan Perpustakaan Universitas Padjajaran. Di USU beliau mengajar mata kuliah Sistem Informasi. 